Research.

\title{
Analysis of bankruptcy issues at manufacturing companies, sub-sectors of cosmetics and house- appliances registered in Indonesia Stock Exchange (IDX) year 2015-2017 using Altman Z-score
}

\author{
Indar Khaerunnisa ${ }^{1^{*}}$, Nur Anisa Rahayu ${ }^{2}$ \\ $1^{1 *}$ Department of Accounting, Economic College of Binaniaga, Bogor, Indonesia \\ ${ }^{2}$ Department of Management, Economic College of Binaniaga, Bogor, Indonesia \\ bundaabdadabsyar@gmail.com (I. Khaerunnisa), nuranisarahayu95@gmail.com (N. A. Rahayu) \\ "Corresponding author
}

Received: March 05, 2019; Accepted: April 15, 2019; Published: June 30, 2019.

To cite this article: Khaerunnisa, Indar, Nur Anisa Rahayu. (2019). Analysis of bankruptcy issues at manufacturing companies, sub-sectors of cosmetics and house-appliances registered in Indonesia Stock Exchange (IDX) year 2015-2017 using altman z-score. The Accounting Journal of BINANIAGA. 4 (1): 27-36. doi:

\begin{abstract}
This research aims to figure out the level of companies bankruptcy by applying Altman Z-Score at the manufacturing companies registered in the Indonesia Stocks Exchange. The result of the research has indicated that $Z$ Score model is applicable to detect the company's potential bankruptcy issues, especially manufacturing company subsectors of cosmetics and houseappliances. Altman Z-Score model has classified the companies into three categories; safe, grey area and distress. Based on the result of the research, for the companies which are in the grey area category are suggested to improve their financial performance and to use the benefit of all the assets properly to get the revenue as much as possible. However, for the companies which are in the safe category are suggested to increase their performance, especially marketing performance so that they will receive bigger amount of the revenue, nevertheless, the potential of financial distress can be minimized accordingly.
\end{abstract}

Keywords: manufacturing company, financial distress, Altman Z-Score.

\section{Introduction}

\section{Background}

Bassically Analysis of company financial statement is the ratio evaluation of the company's financial condition either it is historical circumstances, recently and future probability. Managers have been doing it accordingly since it is very easy. The financial ratio is describing the condition of a company whether it is in a good condition or it is in a decreasing one. If the performance of a company is decreasing, it is suffering from bankruptcy. Bankruptcy is a state of a company or a person which is unable to pay the debts. Bankruptcy is also indicating that the company is deficit or does not have enough money to run its business. In order to avoid a bankruptcy, the company could able to perform a bankruptcy prediction. 
Manufacturing company is an entreprise processing raw materials or semi finished product or work in process. This research is focusing to the company having cosmetics and house appliances subsectiors. The reason of this research is due to the lifestyle of modern Indonesian people who want to have a different and exclusive presentation, it refers to their outfit accessories and fashion. That is why many Indonesian people are eager to spend more money to buy cosmetics to make them more attractive.

Few of the researches have developed model of company bankruptcy prediction. One of them is Altman Z-Score Model. This method has exceedingly more advantages than other bankruptcy prediction method which is it has combined some ratios required to evaluate liquidity, profitability, solvability and activity. Moreover, Z-Score ratio has covered internal and external evaluation of the company, in this case, it is the ratio of company's stocksmarket value against total of all liabilities involved in the method of Altman Z-Score.

Based on the background above, the researcher has formulated it as follows: "Analysis of Bankruptcy Issues at Manufacturing Companies Sub-sectors of Cosmetics and House-Appliances Registered in Indonesia Stock Exchange (IDX) year 2015-2017 using Altman ZScore". However, the purpose of this research is to analyze bankruptcy issues at the manufacturing companies sub-sectors cosmetics and houseappliances based on the financial ratio using Altman Z-Score method and to evaluate the healthy of company's performance specifically in its finance.

\section{The purpose of the Research}

The purposes of the research are as follow:

a. To analyze the bankruptcy issue using Altman Z-Score Method at the manufacturing companies sub-sectors of cosmetics and house appliances registered in IDX for the years of 2015-2017.

b. To figure out the risks analysis of bankruptcy issues at manufacturing companies sub-sectors cosmetics and house appliances registered in IDX for the years of 2015-2017 using Z-Score analysis.

\section{Library Review}

\section{Finance Management}

According to Irham Fahmi (2014:1), company finance management is an integrated sciences and arts describing, studying and analyzing how the finance manager is utilizying all the company's resources to look for the finance, manage the finance and distribute the finance getting the revenue or increasing the prosperity of stakeholders and making sure the sustainability of the company accordingly.

According to Musthafa (2017:2), finance management is an enjoying and challenging science because the people who are interested in finance management will get bigger opportunities working as corporate finance manager, in the bank, in real estate, in insurance company, and in other government sectors, therefore their career are developing.

According to Ni Luh Gede Erni Sulindawati, et.al (2017), finance management is all the company activities relating to obtaining the finance required with minimum cost and profitable requirements and the efforts to use the related finance as efficient as possible.

Indar Khaerunnisa and Nur Anisa Rahayu. Analysis of bankruptcy issues at manufacturing companies, sub-sectors of cosmetics and house-appliances registered in Indonesia Stock Exchange (IDX) year 2015-2017 using Altman Z-score 


\section{Financial Statement}

According to Irham Fahmi (2014:31) financial statement is an information describing finance condition of a company, and furthermore, the related information is usefull to describe the financial performance of the company.

According to Kasmir (2017:6) Financial statement is a report indicating the finance condition of a company at present or in a certain periode.

According to Brigham and Houston (2015:84), financial statement is some papers indicating a lot of figures, however it is useful to study the assets mentioned on the related figures. According to Hery (2016:4), financial statement is an end product of a chain of the process of recording and summarizing the data of business transactions.

\section{Bankruptcy}

Referring to Hanafi (2010:638), Business difficulty is a continuous circumstances starting from small problem of financial issue (such as liquidity) up to the serious problem or unsolvable problem (liabilities are bigger than the assets). At this circumstance, the company practically is considered bankrupt.

According to Supardi and Mastuti in Ardi Al-Maqassary (2013), bankruptcy is a failure of the company running its business to obtain the revenue. Based on the definitions above, it can be concluded that bankruptcy is a condition when liabilities to creditors are bigger than the assets of the company.

\section{Altman Z-Score Analysis} analysis.

Varied researches have studied the benefits of financial ratio

Edward I Altman in New York University is one of the pioneers who is studying the benefit of financial ratio analysis as the tools to predict the bankruptcy of a company. The result of the research of Altman has defined Z-Score equation. This equation is a ratio model using multiple discrimate analysis (MDA).

MDA method is requiring more than one financial ratios related to bankruptcy of a company getting a comprehensive model. Using discriminate analysis, the function of end discriminate is applied to predict the company bankruptcy based on the financial ratios using its variable.

Accordng to Rudianto (2013:254) Analysis Z-Score is a method to predict a company bankruptcy by combining several general financial ratios and defining different weights of Altman Z-Score analysis that was invented by Edward I Altman in 1968 as the output of his research. After selecting 22 financial ratios, he discovered 5 ratios which could be combined to differentiate the companies which were bankrupt and the companies were not bankrupt.. Altman had done several researches using diversified conditions of the companies. Therefore, Altman defined some varied equation to be used in the companies having different circumstances. This model has focused to the probabilities as the most components affecting the bankruptcy. Rudianto (2013:254) describing that the equation developed by Altman is as follows:

Z-Score equation developed by Altman in 1968. And this equation is the output of the research about manufacturing companies selling their shares on the USA stocks-exchange. Neverhteless, this equation is useful to 
predict the continuity of manufacturing companies which have been going public. The origin of equation is as follows:

$Z=1,2 X_{1}+1,4 X_{2}+3,3 X_{3}+0,6 X_{4}+1,0$

Description:

$\mathrm{X}_{1}=$ Total Aset

$\mathrm{X}_{2}=$ Retained Earnings $:$ Total Assets

$\mathrm{X}_{3}=$ EBIT : Total Assets

$\mathrm{X}_{4}=$ Stock market value / total liabilities

$X_{5}=$ Total Aset

Since the scores obtained is the integration of 5 (five) different agents where each agent is varied, so it is very important to understand the meaning of each agent.

According to Rudianto (2013:255), the definition of discriminate Z (zeta) as the following:

a. Ratio X1 (Working Captal : Total asset). Measuring the liquidity by comparing net liquid asset with total asset. Net liquid assets or working capital is defined as current assets deducted by total current liabilities(current assets - current liabilities). In general, if a company is suffering from financial deficit, working capital/current assets will decrease more rapidly than total assets causing this ratio is decreased.

b. Ratio X2 (Retained Earnings : Total assets). This ratio has indicated the probability ratio detecting the ability of the company gaining the revenue refers to the ability of the related company getting the revenue compared to turn- over of current assets as the efficiency of company measurement or by other words, this ratio is measuring the accumulation of the earnings as long as the company that is running its business.

c. Ratio X3 (EBIT : Total Assets). This ratio is measuring the probability of return assets in yearly distribution of the earnings before interest and tax divided by total asset at end year of balance sheet. This ratio is describing the important of earnings achievement of the company especially in connection with the interest rate payment to the investors.

d. Ratio X4 (Shares value : Total Liabilities). This ratio is on the contrary of Debt to Equity Ratio. Equity ratio value is the shares value on the stockmarket which is the total of company's shares multipled by each share on the stockmarket (total of the shares $x$ price of each share on the stockmarket). In general, the companies which are failed will accumulate their liabilities compared to current equity.

e. Ratio X5 (Sales : total Asset). This ratio has been measuring the management capability to utilize the assets to achieve the sales target which is the keyfactor of the company running its business.

Referring to Rudianto (2013:256), Altman describing that if a company is having 2.99 or more of bankruptcy index, the related company is not categorized bankrupting. However, the company that is having 1.81 or less than bankruptcy index, the related company is within bankruptcy category. Result of the calculation using Z-Score equation will indicate a diversified score between one company to another ones. The score should have to be compared with the following standard of evaluation to judge the continuity of the related company:

a. If $Z$ value $>2.99=$ safe / green zone

b. If the value of $1.81<Z<2.99=$ grey area

Indar Khaerunnisa and Nur Anisa Rahayu. Analysis of bankruptcy issues at manufacturing companies, sub-sectors of cosmetics and house-appliances registered in Indonesia Stock Exchange (IDX) year 2015-2017 using Altman Z-score 
c. If the value of $Z<1.81=$ dangerous zone.

\section{Research Design}

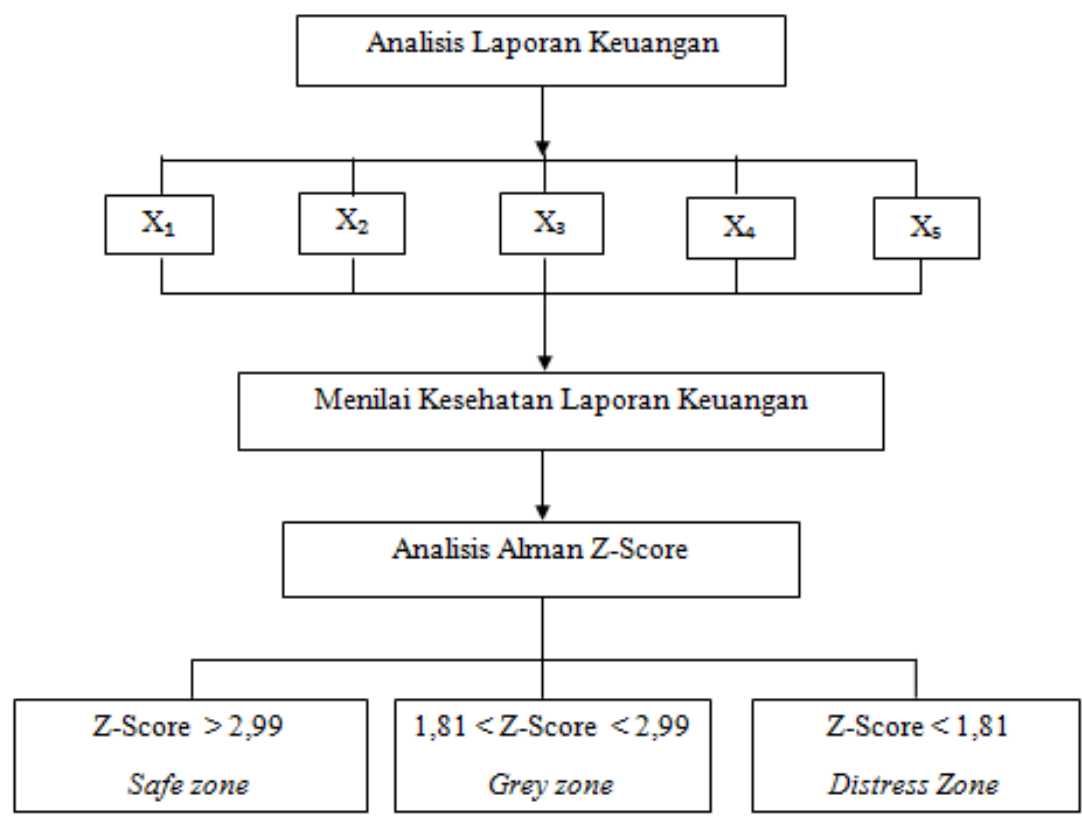

Figure 1

\section{Design Research}

Description

$\mathrm{Z}=$ Overall Index or Score

$\mathrm{X}_{1}=$ Working Capital to Total Assets

$\mathrm{X}_{2}=$ Retairned Earning to Total Assets

$X_{3}=$ Earning Before Income Tax and Taxes to Total Asset

$X_{4}=$ Market Value of Equity to Total Liabilities

$X_{5}=$ Sales to Total Asset

\section{Research Methodology}

\section{Location and Time of the Research}

The research has taken manufacturing companies sub-sectors of cosmetics and house appliances registered in IDX year 2015-2017 by downloading the data on IDX website www.idx.co.id. The research has occupied about three months, starting October 2018 to December 2018. During this period of time, the writer has prepared some stages of the research starting the preparation of the research till the evaluation of it.

\section{Research Method}

This research has applied descriptive research. Referring to Sekaran (2009:158-160) Descriptive research is a research to figure out and to describe the characteristics of variables studied within a particular circumstance. Referring Sugiyono (2010:11) descriptive research is the research to figure out the value of independent variablea, either one variable or more than one variables. 


\section{Population and Sample}

Referring Sugiyono (2010:115) population is a generalized area consisting of object/subject having quality and particular characteristics defined by the researcher to be studied and to be concluded furthermore. The population of this research is all the industrial manufacturing companies sub-sectors cosmetics and houseappliances for the periode of 2015-2017.

Referring to Sugiyono (2014:81) sample is a part of quantity and characteristics owned by the related population. Technique of this research has applied saturated sampling, since the population is relatively small. And refers to Sugiyono $(2014: 85)$ saturated sampling is a technique defining the sample when all the members of a population are considered as the samples.

\section{Method of Data Collected}

Method of data collected which has been applied in this research is library study and documentation.

a. Library study is to read many related books or journals in the library and internet which is the references related to the research.

b. Documentation is to gather, to take a note and to study the documents related to the data of company's finance subsectors cosmetics and house-appliance for the period of 2015-2017 which is downloaded from website of www.idx.co.id.

\section{Type and Resource of the Data}

Type of the data applied in this research is quantitative data taken based on the financial statements of manufacturing companies sub-sectors cosmetics and house-appliances during the period of the research. Resources of the data applied is the secondary data taken from legal website of Indonesian Stocks Exchange www.idx.co.id.

\section{Method of Data Analysis}

Method of data analysis applied in this research is descriptive data analysis using Altman Z-Score Method which is the following equation:

$Z=1,2 X_{1}+1,4 X_{2}+3,3 X_{3}+0,6 X_{4}+1,0 X_{5}$

Description:

$\mathrm{X}_{1}=$ Working Capital / Total Assets

$\mathrm{X}_{2}=$ Retained revenue / Total Assets

$\mathrm{X}_{3}=\mathrm{EBIT} /$ Total Assets

$\mathrm{X}_{4}=$ Equity Book Value / Total Liabilities

$X_{5}=$ Sales Revenue $/$ Total Assets company:

The following standard of the evaluation is to evaluate continuity of the

a. If the value of $Z>2.99=$ Safe Zone

b. If the value of $1.8<Z<2.99=$ grey zone

c. If the value of $Z<1.8=$ distress zone

Indar Khaerunnisa and Nur Anisa Rahayu. Analysis of bankruptcy issues at manufacturing companies, sub-sectors of cosmetics and house-appliances registered in Indonesia Stock Exchange (IDX) year 2015-2017 using Altman Z-score 


\section{Result and Description}

\section{Description}

Population of this research is cosmetics and house-appliances companies registered at IDX in 2015-2017 and is using 6 samples of the companies which are having proper financial statements. The result of ZScore value of each company is indicated on the following graph.

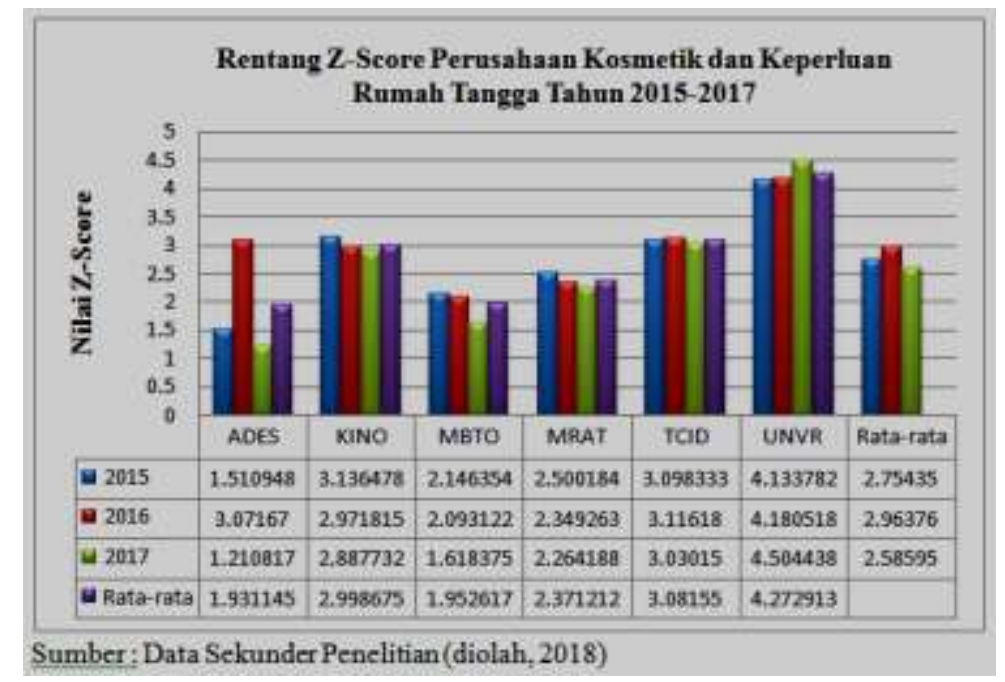

Figure 2.

Graph of Altman Z-Score value of 6 companies subsectors cosmetics and house-appliances.

Figure 2 above has described that in 2015 average Z-Score of subsectors cosmetics and house-appliances was 2.754, so that, it could predict that the companies which had been on a higher than the average; PT Unileer Tbk os 4.133, PT Mandom Indonesia TBK of 3.098, PT Kino Indonesia TBK of 3.136. And the companies under the average were PT Mustika Ratu Tbk of 2.500, PT Martina Berto Tbk of 2.146, PT Akasha Wira International Tbk of 1.510. Result of the research is getting along with the previous researches which is Nurul and Mirza (2018)

In 2016 average of Z-Score of all companies sub-sectors cosmetics and house-appliances of 2.963 , so that, it could predict that the companies which had had the scores higher than the average of the industry as the following: PT Unilever Tbk of 4.180, PT Mandom Indonesia of 3.116, PT Akasha Wira International of 3.071, PT Kino Indonesia Tbk of 2.971. And the companies which had been below the average as follows: PT Mustika Ratu Tbk of 2.349. PT Martina Berto Tbk of 2.093. This result is getting along with the previous research of Nurul and Mirza (2018).

In 2017, the average Z-Score of all companies, subsectors cosmetics and house-appliance was 2.585 , it could predict that the industries above average were :PT Unilever Tbk score of 4.504, PT Mandom Indonesia score of 3.030, PT Kino Indonesia Tbk score of 2.887. However the industries below the average were: PT Mustika Ratu Tbk score of 2.264, PT Martina Berto Tbk score of 1.618, PT Alasha Wira International of 1.210.

After analyzing the evaluation of each variable (X1, X2, X3, X4, X5) during the three years, it has indicated that three companies, subsectors 
cosmetics and house appliances are within category of safe area, they are PT Unilever Indonsia Tbk, PT Mandom Indonesia Tbk, and PT Kino Indonesia Tbk. However, three companies are within the category of grey area or, on other words, PT Mustika Ratu Tbk, PT Martina Berto Tbk, and PT Akasha Wira International Tbk have been facing potential bankrupt. The six companies for three years continuously have been predicted within potential grey area. It has indicated that the related companies should have focused on their improvement of their company performance related to the five ratios, for example, increasing sales volume of their ready stocks to get the revenue. Furthermore, they could modify or add intangible assets.

Intangible assets are company management system, loan from second party either bank or other company, support from the state(subsidiary), mutual contract agreement with popular company. Based on the condition above, the management should have to be more careful and should have performed rapid correction.

\section{Conclusion and Suggestions}

\section{Conclusion}

Based on the research above, the writer has concluded as follows:

a. From the result of the research done by the researcher, three manufacturing companies subsectors cosmetics and houseappliance are within strong $\mathrm{Zi}$ value or they are defined as healthy companies. The related companies are PT Unilever Indonesia Tbk, PT Mandom Indonesia Tbk and PT Kino Indonesia Tbk having high Z-Score value because they have had good financial statement indicated by the increasing of their liquidity, increasing of either net revenue or revenue before tax, and positive sales trending. However, manufacturing companies subsectors cosmetics and houseappliances having fluctuative $\mathrm{Zi}$ score will be good at a certain period of time but in the next period they will be categorized weak or potential bankrupt. PT Mustika Ratu Tbk, PT Martinia Berto Tbk, and PT Akasha Wira International Tbk are within this category because they have had ZScore quite small due to some factors or low sales, low revenue and lack of working capital running their business. Some strategies that could be taken by the companies due to the problems above, they should have been focusing to the improvement of their performance, increasing sales volume upon their stock of goods to get the revenue. The companies which are within potential bankrupt, their management should have to be more aware of it and to perform the improvement as soon as possible avoiding bankruptcy during the next period of time.

b. Altman Z-Score analysis predicting the bankruptcy issue at PT Akasha Wira International Tbk which has got mean value of 1.931 which is on the grey zone or it is indicated potential bankrupt. Altman Z-Score analysis has predicted the bankruptcy issue at PT Kino International Tbk due to its mean value of 2.988 which is it is within safe position or the company is safe. Altman Z-Score analysis has predicted the bankruptcy issue at T Martina Berto Tbk due to its mean value of 1.952 indicating it is in grey zone or the company is potentially bankrupt. Altman Z-Score analysis has predicted the bankruptcy issue at PT Mustika Ratu Tbk due to its mean value of 2.371 which is it is in grey zone or potential bankrupt. However, Altman Z-Score analysis has predicted the bankruptcy issue at PT Mandom Indonesia Tbk due to its mean value of 3.081 which is it in a safe zone or the company is safe.

Indar Khaerunnisa and Nur Anisa Rahayu. Analysis of bankruptcy issues at manufacturing companies, sub-sectors of cosmetics and house-appliances registered in Indonesia Stock Exchange (IDX) year 2015-2017 using Altman Z-score 
Altman Z-Score analysis has predicted the bankruptcy issue at PT Unilever Indonesia Tbk, due to its mean value of 4.272 and it is in the safe zone or the company is safe.

\section{Suggestions}

Based on the conclusion above, the writer has suggested as follows:

a. For the companies which are in the grey area, they should have to be fully aware of having potential bankrupt, however, they should have to increase their financial performance improvement by increasing current assets, total assets, equities, sales, retained revenue or EBIT.

b. For the companies which are not in the position of bankrupt, they should have to develop and improve their financial performance in order to avoid any potential bankrupt.

c. Expected future research can use other bankruptcy prediction models in order using them as the comparison tools of the bankruptcy prediction.

\section{References}

Altman, E. I. and Edith Hotckiss. (2006). Corporate Financial distress and Bankruptcy: Predict and Avoid Bankruptcy, Analyze and Invest in Distressed Debt, Third Edition. Canada: John Wiley \&Sons, Inc., Hoboken, New Jersey.

Brigham, E.F., Joel, F.H. (2015). Dasar-dasar Manajemen Keuangan, Edisi 11. Jakarta: Salemba Empat.

Fahmi, I. (2014). Manajemen Perusahaan dan Pasar Modal, Edisi Pertama. Jakarta: Mitra Wacana Media.

Febrianasari, H. N. (2012). Analisis Penilaian Financial Distress Menggunakan Model Altman (Z-Score) Pada Perusahaan Kosmetik yang Tercatat di Bursa Efek Indonesia. Jurnal Akuntansi Unesa. 1 (1).

Hanafi, M. M. Halim, A. (2016). Analisis Laporan Keuangan. Yogyakarta: UPP STIM YKPN.

Hery. (2016). Analisis Laporan Keuangan. Jakarta: Grasindo.

Kasmir. (2017). Analisis Laporan Keuangan, Edisi 1-10. Jakarta: Rajawali Pers.

Kelana, I. (2014). Pengaruh Struktur Kepemilikan Dan Kebijakan Dividen Terhadap Nilai Perusahaan Pada Sektor Manufaktur Sub Sektor Kosmetik Dan Perlengkapan Rumah Tangga Yang Terdaftar Di Bursa Efek Indonesia Tahun 2003-2012.

Kenamon, M., Yetti, D.W., Haninun. (2018). Prediksi Kebangkrutan Dengan Model Altman Z-Score Pada Perusahaan Farmasi Yang Terdaftar Di Bursa Efek Indonesia Periode 2012-2016. Jurnal Akuntansi dan Keuangan. 9 (1).

Musthafa. (2017). Manajemen Keuangan. Yogyakarta: CV. Andi Offset.

Noviandani, N., Mirza, S.A.P. (2018). Analisis Altman Z-Score Untuk Memprediksi Kebangkrutan Pada Perusahaan Manufaktur Sector Barang Konsumsi di Indonesia. Proceeding, The National Conferences Management and

Indar Khaerunnisa and Nur Anisa Rahayu. Analysis of bankruptcy issues at manufacturing companies, sub-sectors of cosmetics and house-appliances registered in Indonesia Stock Exchange (IDX) year 2015-2017 using Altman Z-score 
The Accounting Journal of BINANIAGA Vol. 04, No. 01, June 2019

p-ISSN: $2527-4309$, e-ISSN: $2580-1481$

$5^{\text {th }}$ Accreditation Rating: January 14, 2019 - January 13, 2024

Business (NCMAB) 2018.

Rudianto. (2013). Akuntansi Manajemen. Jakarta: Erlangga.

Sekaran, U., Roger, B. (2009). Research Method for Business, Fifth Edition. New York: John Wiley \& Sons. Inc.

Sulindawati, N.L.G.E. (2017). Manajemen Keuangan Sebagai Dasar Pengambilan Keputusan Bisnis, Edisi 1. Depok: Rajawali Pers

Sugiyono. (2010). Metode Penelitian Bisnis. Bandung: Alfabeta.

www.sahamok.com

Indar Khaerunnisa and Nur Anisa Rahayu. Analysis of bankruptcy issues at manufacturing companies, sub-sectors of cosmetics and house-appliances registered Page : 36

in Indonesia Stock Exchange (IDX) year 2015-2017 using Altman Z-score 